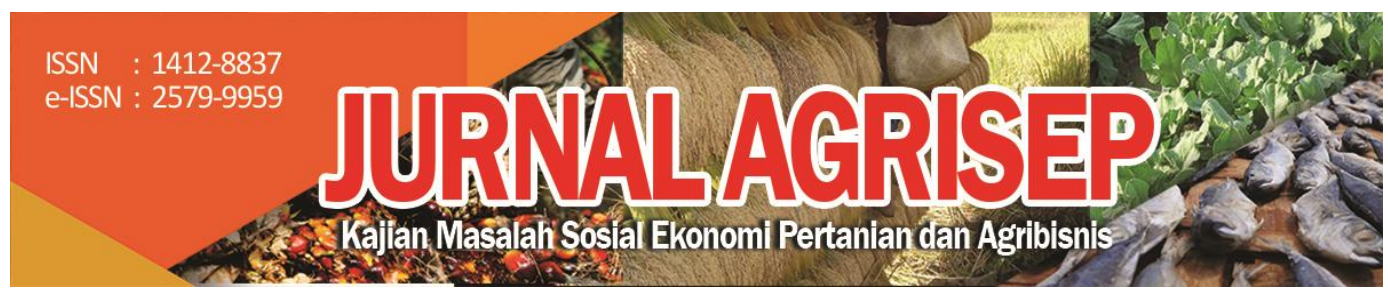

DOI: 10.31186/jagrisep.20.2.397-410

\title{
ANALISIS FAKTOR-FAKTOR YANG MEMPENGARUHI PENDAPATAN RUMAH TANGGA PETANI KARET DESA BENTENG HARAPAN KECAMATAN MAJE KABUPATEN KAUR
}

\author{
Analysis of Factor that Infenence the Rubber Farmers Household Income \\ (Casy Study: In Benteng Harapan Village, Maje District, Kaur Regency) \\ Parda Oka Aulina'); Sriyoto ${ }^{1}{ }$; Ellys Yuliarti1) \\ 1) Program Studi Agribisnis, Fakultas Pertanian, Universitas Bengkulu, \\ Bengkulu, Indonesia \\ Email: sriyotounib@gmail.com
}

\begin{abstract}
The purpose of this research is to 1) examine the revenue of rubber farmer households; 2) Analyze the expenditure of rubber farmer households; 3) analyze of income of rubber farmer households; and 4) factor affect the households income of rubber farmers in Benteng Harapan Village, Maje District, Kaur Regency. The study was conducted in October 2019. Methods of Data Analysis using quantative analysis for income of rubber farmers and multiple linear regression Analysis. The research sample of 55 respondents. The results showed that revenue farmer household was IDR 6.026.650/month, household expenditure of IDR 5.084.291/ month, income household was IDR942.359/month. Factors affecting income rubber farmers household are the price of rubber, rubber farming experienced, and side jobs. Farmers are expected to be able to maintain the quality of their latex rubber, that is, not to mix other objects so that it weighs on the scales. In marketing rubber, farmers should always be organized, traders should not try to suppress the buying price of rubber
\end{abstract}

Keyword: Rubber, income, revenue, expenditure

\section{ABSTRAK}

Studi ini bertujuan untuk 1) menganalisis penerimaan rumah tangga petani karet; 2) menganalisis pengeluaran rumah tangga petani karet; 3) menganalisis pendapatan rumah tangga petani karet; dan 4) mengetahui faktor-faktor yang mempengaruhi pendapatan rumah tangga petani karet di Desa Benteng Harapan 
Kecamatan Maje Kabupaten Kaur. Penelitian ini dilakukan pada Bulan Oktober 2019. Data yang diperoleh dianalisis dengan metode kuantitatif dalam menghitung pendapatan rumah tangga petani dan regresi linear berganda. Sampel dalam studi ini berjumlah 55 orang petani. Hasil penelitian menyatakan bahwa penerimaan rumah tangga petani sebesar Rp6.026.650/bulan, pengeluaran sebesar Rp5.084.291/bulan, dan pendapatan sebesar Rp942.359/bulan. Harga karet, pengalaman berusahatanni karet, dan pekerjaan sampingan merupakan variabel yang berpengaruh nyata terhadap pendapatan rumah tangga petani karet. Umur petani, pendidikan, dan luas lahan merupakan variabel yang tidak berpengaruh nyata. Para petani karet diharapkan dapat menjaga kualitas karet lateksnya, yaitu jangan mencampurkan benda lain sehingga memberatkan timbangan. Di dalam pemasaran karet para petani hendaknya selalu diorganisir, para pedagang hendaknya tidak berusaha untuk menekan harga beli karet.

Kata Kunci: karet, pendapatan, penerimaan dan biaya

\section{PENDAHULUAN}

Indonesia merupakan negara agraris dengan sumberdaya alam yang kaya, pertanian menjadi sumber penghasilan bagi penduduk Indonesia. Sektor pertanian memiliki nilai ekonomi yang tinggi sehingga nilai ekonomi yang didapatkan dapat menopang hidup masyarakat. Program pembangunan pertanian selaras dengan peningkatan pendapatan masyarakat dan taraf hidupnya. Program pembangunan dapat membuka usaha pasar bagi produk pertanian dan ksempatan kerja (Nugraha dan Alamsyah, 2019).

Salah satu komoditas perkebunan, yaitu karet memiliki nilai ekonomi tinggi dan bernilai strategi dalam meningkatkan pendapatan petani karet. Komoditi penghasil getah ini banyak diandalkan oleh masyarakat, karena komoditi karet mudah diusahakan dan cocok ditanam di Indonesiayang beriklim tropis. Di Indonesia komoditi karet menjadi salah satu hasil pertanian terbaik karena memiliki arti penting dan menunjang perekonomian negara (Juliansyah dan Riyono, 2018).

Komoditas karet di Indonesia adalah salah satu tanaman perkebunan yang memiliki andil penting, baik dari segi ekonomi maupun sosial. Hal ini disebabkan oleh penyebaran dan pengusahaan tanaman karet yang cukup luas dan tersebar bebagai wilayah Indonesia. Selain itu tanaman karet banyak menyertakan tenaga kerja pada berbagai tahap kegiatan (Ali dkk, 2015). Komoditas karet di Provinsi Bengkulu memiliki potensi yang cukup besar untuk dikembangkan. Hal ini dikarenakan komoditas karet yang memiliki pengaruh penting sebagai penyerapan tenaga kerja setempat, sumber pendapatan masyarakat, penghasil devisa, dan kontribusi terhadap Produk Domestik Regional Bruto (PDRB). Permasalahan komoditas karet yang dihadapi sampai saat ini oleh petani karet adalah rendanya produktivitas. Menurut Said dan Junedi (2008), tingginya jumlah tanaman yang berumur tua dan menggunakan klon asalan menjadi penyebab rendahnya produktivitas

398 | Parda Oka Aulina, Sriyoto, Ellys Yuliarti1; Analisis Faktor-faktor Yang ... 
tanaman karet rakyat. Rendahnya tingkat produktifitas karet yang dicapai oleh perkebunan karet rakyat yaitu sebesar $991 \mathrm{Kg} / \mathrm{Ha} / \mathrm{Tahun}$. Kondisi ini akan berdampak pada rendahnya pendapatan petani karet dan juga pendapatan rumah tangga petani.

Masyarakat pada Desa Benteng Harapan, Kecamatan Maje, Kabupaten Kaur sebagian besar bekerja sebagai petani karet. Komoditas karet menjadi andalan petani karena topografi wilayahnya sangat cocok dengan komoditas tersebut. Hal ini didukung dengan kondisi lahan dan luas daerah di Kabupaten Kaur untuk tanaman karet, sehingga wilayah ini banyak dimanfaatkan sebagai lahan perkebunan karet. Perkebunan karet dikelola oleh perusahaan pemerintah (Perkebunan Nusantara) dan oleh masyarakat. Hingga saat ini luas lahan tanam sebesar 410 ha dan produksi sebanyak 40rb ton pertahunnya. Kondisi tersebut dinilai sangat potensial untuk mengusahakan karet. Akan tetapi saat ini petani menjelaskan harga karet dari waktu ke waktu mengalami penurunan dan produktivitasnya yang masih rendah. Hal ini akan menyebabkan rendahnya pendapatan petani karet. Banyak aspek yang mempengaruhi tinggi dan rendahnya pendapatan rumah tangga petani karet seperti: luas lahan, umur petani, pendidikan petani, harga karet, pengalaman usahatani karet dan pekerjaan sampingan. Tujuan penelitian ini 1) menganalisis penerimaan, pengeluaran, pendapatan rumah tangga petani karet; 2) menganalisis faktor-faktor yang mempengaruhi pendapatan rumah tangga petani karet.

\section{METODE PENELITIAN}

\section{Metode Penentuan Lokasi, Responden dan Pengumpulan Data}

Studi ini dilakukan pada Desa Benteng Harapan Kecamatan Maje Kabupaten Kaur. Lokasi penelitian ditentukan berdasarkan metode purposive yang ditentukan secara sengaja. Lokasi tersebut dipilih berdasarkan populasi terbesar petani karet yang berada di Desa Benteng Harapan Kecamatan Maje. Populasi yang digukan adalah rumah tangga petani karet. Petani karet dilokasi penelitian adalah berjumlah 120 orang petani. Penentuan jumlah responden dilakukan dengan teknik Simple Random Sampling (sample acak sederhana). Dalam penentuan responden dilakukan dengan menggunakan metode Slovin, dimana jika populasi lebih dari 100 responden dapat diambil tingkat toleransi kesalahan sebesar 5\% - 10\% (Sugiyono, 2002). Pada studi ini dipakai tingkat kesalahan $10 \%$. Untuk mengetahui jumlah responden digunakan rumus sebagai berikut:

$$
n=\frac{N}{1+N e^{2}}
$$

Dimana: $\mathrm{N}$ : Jumlah populasi, $\mathrm{n}$ : Jumlah sampel, dan e : tingkat kesalahan 


$$
n=\frac{120}{1+120(0,1)^{2}}=54,5 \approx 55 \text { orang }
$$

Data primer merupakan salah satu jenis data yang dipakai pada penelitian ini. Data primer dalam studi ini didapatkan melalui wawancara langsung dengan responden berdasarkan kuisioner yang telah disusun sebelumnya. Sedangkan data sekunder yang digunakan didapatkan melalui jurnal ilmiah, studi pustaka, instansi terkait dengan topik penelitian.

\section{Metode Analisis Data}

\section{Analisis Penerimaan Rumah Tangga Petani Karet}

Analisis penerimaan dilakukan dengan menguraikan struktur penerimaan petani berdasarkan sumber-sumber penerimaan yang ada. Total penerimaan dihitung dari seluruh hasil berupa uang real yang diperoleh oleh petani dari hasil kegiatan baik dari sektor pertanian ataupun non pertanian dalam satu periode. 2016)

Analisis penerimaan petani dilakukan dengan cara berikut (Soekartawi,

a. Penerimaan Usahatani

Untuk menghitung total penerimaan usahatani karet dengan menggunakan rumus sebagai berikut:

$$
T R=Y \times P y
$$

Dimana : TR : Total penerimaan usahatani (Rp/bulan), Y : Produksi (Kg/bulan), dan Py : Harga jual (Rp/kg)

b. Penerimaan Rumah Tangga Petani Karet

$$
Y=\sum_{i=1}^{n}(P)_{1}+\sum_{j=1}^{m}(N P)_{1}
$$

Dimana : Y: Seluruh penerimaan rumah tangga petani karet (Rp/bulan), P : Penerimaan dari kegiatan usaha pertanian (Rp/bulan), NP: Penerimaan dari usaha non pertanian (Rp/bulan), i : 1...n : usahatani di beberapa sub sektor pertanian dari rumah tangga, dan $\mathrm{j}: 1 \ldots \mathrm{m}$ : non usahatani dari berbagai kegiatan rumah tangga

\section{Analisis Pengeluaran Rumah Tangga Petani Karet}

Analisis pengeluaran rumah tangga petani dilakukan dengan mengurangkan struktur pengeluaran rumah tangga petani berdasarkan jenis pengeluaran, baik dari pengeluaran untuk kegiatan pertanian ataupun non pertanian. Rumus yang digunakan adalah rumus yang diformulasikan oleh Soekartawi (2016) sebagai berikut: 


$$
Y=\sum_{i=1}^{n}(P)_{1}+\sum_{j=1}^{m}(N P)_{1}
$$

dimana $: Y \quad$ : Seluruh pengeluaran rumah tangga petani karet (Rp/bulan), $\mathrm{P}$ : Pengeluaran dari kegiatan usaha pertanian (Rp/bulan), NP: Pengeluaran dari usaha non pertanian (Rp/bulan), i $: 1 \ldots n$ : usahatani di beberapa sub sektor pertanian dari rumah tangga, dan $\mathrm{j}: 1$...m : non usahatani dari berbagai kegiatan rumah tangga

\section{Analisis Pendapatan Rumah Tangga Petani Karet}

Pendapatan adalah selisih antara seluruh penerimaan rumah tangga petani karet dengan seluruh pengeluaran rumah tangga petani karet. Pendapatan dirumuskan sebagai berikut:

$$
I=T R-T C
$$

Dimana : I : Pendapatan (Rp/bulan), TR : Seluruh penerimaan ( $\mathrm{Rp} /$ bulan), TC : Seluruh pengeluaran ( $\mathrm{Rp} /$ bulan)

\section{Analisis Faktor-faktor yang Memengaruhi Pendapatan Rumah Tangga Petani Karet}

Pada bagian ini dilakukan analisis aspek-aspek yang berpotensi mempengaruhi pendapatan rumah tangga petani karet dengan metode regresi linier berganda dengan model yang formulasikan oleh Gujarati (2010). Dalam penelitian ini diasumsikan pendapatan per bulan $(\mathrm{Y})$ merupakan fungsi daro Umur petani (X1), tingkat Pendidikan (X2), Luas Lahan karet (X3), Harga karet (X4), pengalaman usahatani (X5) dan variabel Dummy (D) yang merepresentasikan pekerjaan sampingan dimana $\mathrm{D}=1$, jika memiliki pekerjaan sampingan dan $\mathrm{D}=0$ sebailiknya jika tidak memiliki pekerjaan sampingan. Secara ekonometrika, model pendapatan rumah tangga petani karet dituliskan sebagai berikut:

$$
Y=b_{0}+b_{1} X_{1}+b_{2} X_{2}+b_{3} X_{3}+b_{4} X_{4}+b_{5} X_{5}+D+e
$$

dimana: $b_{0}:$ Konstanta, $b_{1}-b_{6}:$ Koefisien regresi dan e : Error term

\section{HASIL DAN PEMBAHASAN}

\section{Karakteristik Petani Karet}

Hasil studi menunjukkan bahwa petani dengan umur di atas 40 tahun memiliki persentase yang tinggi mengindikasikan pekerjaan sebagai petani karet jarang diminati oleh kaum muda. Kaum muda lebih terdorong atau cenderung bekerja di luar sektor pertanian dan mereka beranggapan bahwa pekerja di sektor pertanian atau sebagai petani terkesan kumuh atau kotor. 
Rata-rata tingkat pendidikan petani karet adalah tamat sekolah dasar (SD) dan rendahnya tingkat pendidikan karena keterbatasan ekonomi orang tua. Di samping itu orang tua mereka beranggapan bahwa anak-anak mereka apabila nantinya ingin mengurus usaha di sektor pertanian, tidak perlu dibekali latar belakang pendidikan formal yang tinggi, namun lebih kepada pemberian keterampilan di sektor pertanian dan juga perlunya pengalaman.

Rumah tangga petani karet pada dlokasi studi memiliki jumlah tanggungan keluarga rata-rata sebanyak 3 orang. Apabila dikaitkan dengan perolehan pendapatan rumah tangga petani sebesar Rp 924.359/bulan, artinya dalam upaya mencukupi kebutuhan keluarga petani karena sudah cukup dan pendapatannya dapat digunakan sebagai investasi atau modal usaha dalam berusahatani.

Rerata-rata luas lahan usahatani karet yang dipunyai oleh rumah tangga petani karet sebesar 1,26 hektar, dengan status kepemilikan lahan merupakan kepunyaan pribadi. Dengan demikian petani karet di lokasi penelitian dapat mengatur sektor pertanian dalam upaya dalam memenuhi keluarga melalui pendapatan yang mereka peroleh dari usahatani yang dikerjakan oleh petani.

\section{Penerimaan Rumah Tangga Petani Karet}

Nilai barang dan jasa yang diperoleh selama kurun waktu tertentu diartikan sebagai penerimaan rumah tangga petani. Sumber penerimaan rumah tangga petani karet berasal dari usaha pada sektor pertanian dan usaha pada sektor non pertanian. Hasil penelitian di peroleh bahwa asal penerimaan di sektor pertanian (seperti: penerimaan usahatani karet, tanaman pangan atau padi sawah, dan peternakan). Penerimaan sektor non pertanian meliputi penerimaan sektor jasa, upah buruh, dan penerimaan bukan upah. Rata-rata penerimaan rumah tangga petani karet disajikan pada Tabel 1.

Penerimaan rumah tangga petani karet sebesar Rp3.787.810/bulan, lebih besar dibandingkan dengan penerimaan di sektor non pertanian (Rp2.238.840/bulan). Hal ini mengindikasikan bahwa sektor pertanian merupakan pekerjaan utama, sehingga petani dan keluarganya lebih intensif dalam kegiatan usahatani, sedangkan sektor non pertanian merupakan pekerjaan sampingan, dimana pekerjaan ini kadang-kadang ada dan tidak. Dengan demikian perolehan penerimaannya kecil. 
Tabel 1. Rata-Rata Penerimaan Rumah Tangga Petani Karet

\begin{tabular}{clr}
\hline No & \multicolumn{1}{c}{ Uraian } & Rp/bulan \\
\hline 1 & Penerimaan Sektor Pertanian & \\
& a. Usahatani karet & 2.002 .727 \\
& b. Tanaman pangan & 1.402 .083 \\
& c. Peternakan & 383.000 \\
& Total penerimaan & 3.787 .810 \\
\hline 2 & Penerimaan Sektor Non Pertanian & \\
& a. Pekerjaan sektor jasa & 838.461 \\
& b. Upah buruh & 1.095 .833 \\
& c. Bukan upah atau kiriman & 304.545 \\
& Total penerimaan & 2.238 .840 \\
\hline 3 & Penerimaan rumah tangga petani karet & 6.026 .650 \\
\hline
\end{tabular}

Sumber: Data primer diolah, 2019

\section{Pengeluaran Rumah Tangga Petani Karet}

Pengeluaran pada rumah tangga petani karet berasal dari pengeluaran sektor pertanian dan non pertanian. Pengeluaran sektor pertanian seperti pengeluaran usahatani karet, tanaman pangan, dan peternakan. Sedangkan pengeluaran non pertanian seperti pengeluaran konsumsi, listrik, pendidikan, kesehatan dan kegiatan sosial. Tabel 2 menyajikan rata-rata pengeluaran rumah tangga petani karet.

Tabel 2. Rata-rata pengeluaran rumah tangga petani karet

\begin{tabular}{llr}
\hline No & \multicolumn{1}{c}{ Uraian } & Rp/bulan \\
\hline \multicolumn{3}{c}{ Pengeluaran Sektor Pertanian } \\
1 & a. Usahatani karet & 993.943 \\
& b. Tanaman pangan & 913.810 \\
& c. Peternakan & 170.000 \\
& Total pengeluaran & 2.078 .110 \\
\hline \multicolumn{3}{c}{ Pengeluaran Sektor Non Pertanian } \\
& a. Konsumsi & 1.099 .346 \\
& b. Listrik & 186.982 \\
& c. Pendidikan & 594.556 \\
& d. Kesehatan & 516.346 \\
& e. Kegiatan sosial & 618.932 \\
& Total Pengeluaran & 3.006 .181 \\
\hline 3 & Pengeluaran rumah tangga petani karet & 5.084 .291 \\
\hline
\end{tabular}

Sumber: Data primer diolah, 2019 
Dari Tabel 2., hasil penelitian menunjukkan bahwa pengeluaran sektor pertanian yaitu usahatani karet dan tanaman pangan pengeluarannya per bulannya cukup besar. Hal ini dikarenakan usahatani diusahakan secara intensif sehingga memerlukan biaya yang cukup besar, sedangkan usaha peternakan dilakukan secara tradisional dengan memelihara ayam kampung dan kambing dengan biaya yang kecil atau sedikit. Pengeluaran sektor non pertanian, pengeluaran konsumsi memiliki porsi terbesar yaitu Rp1.099.346/bulan dari pengeluaran sektor non pertanian sebesar Rp3.006.181/bulan, dengan jumlah tanggungan rata-rata sebanyak 3 orang. Hal ini menunjukkan bahwa rumah tangga petani karet dalam upaya memenuhi kebutuhan konsumsi bagi keluarga diutamakan. Disamping itu rumah tangga petani karet juga sudah memperhatikan pendidikan bagi anak-anaknya, juga kesehatan bagi keluarganya serta kegiatan sosial kemasyarakatan. Hal ini ditunjukkan oleh adanya pengeluaran yang cukup besar untuk setiap bulannya.

\section{Pendapatan Rumah Tangga Petani Karet}

Pendapatan rumah tangga petani karet didapat dari selisih antara penerimaan dengan pengeluaran rumah tangga petani karet. Pendapatan rumah tangga petani dapat digunakan selaku ukuran tingkat kesejahteraan (welfare) bagi keluarga petani. Pendapatan rumah tangga petani yang semakin tinggi dapat dikatakan memiliki tingkat kesejahteraan yang lebih baik dan sebaliknya. Mengenai pendapatan rumah tangga petani karet di daerah penelitian dapat dilihat pada Tabel 3.

Tabel 3. Rata-rata pendapatan rumah tangga petani karet

\begin{tabular}{clr}
\hline No & Uraian & Rp/bulan \\
\hline 1 & Penerimaan rumah tangga petani karet & 6.026 .650 \\
2 & Pengeluaran rumah tangga petani karet & 5.084 .291 \\
3 & Pendapatan rumah tangga petani karet & 942.359 \\
\hline
\end{tabular}

Sumber: Data primer diolah, 2019

Di daerah penelitian, pendapatan rumah tangga petani karet sebesar Rp924.359/bulan. Dengan pendapatan tersebut dapat dikatakan terbilang cukup tinggi, kerena ini merupakan pendapatan yang disisihkan setiap bulan dan dapat dijadikan sebagai investasi. Sementara penelitian Mardiana dkk (2014), mengatakan bahwa pada Kecamatan Bumi Agung Kabupaten Way Kanan Provinsi Lampung perolehan pendapatan rumah tangga petani karet rakyat adalah sebesar Rp2.193.324/bulan. Tingginya pendapatan ini karena sumbangan pendapatan dari pendapatan onfarm utama yaitu usahatani karet rakyat dan tanaman karet di daerah ini diusahakan secara intensif. 
Hasil anslisis pendapatan usahatani karet didaerah penelitian diperoleh nilai sebesar Rp1.008.784/bln/ha dan apabila diperhitungkan selama 1 tahun yaitu nilai sebesar Rp20.017.564/tahun/ha. Penelitian Wulansari dkk (2012) dan Natalia dkk (2013) menyatakan bahwa pendapatan usahatani karet selama 1 tahun diperoleh pendapatan sebesar Rp10.116.426/ha dan sebesar Rp13.042.356/ha. Rendahnya pendapatan ini disebabkan rendahnya harga karet. Hasil penelitian Miranda dkk (2015) mengatakan bahwa pendapatan usahatani karet di Desa Pangmilang Kecamatan Singkawang Selatan Kota Singkawang Kalimantan Barat adalah sebesar Rp12.974.800/tahun/ha, dan pendapatan yang rendah ini disebabkan rendahnya harga karet yaitu Rp10.000/kg. Sementara penelitian Devi (2015), Wulandari et.al (2021) dan Endang (2013) mengatakan bahwa pendapatan usahatani karet sebesar Rp25.467.981/tahun/ha, Rp21.142.903/tahun/ha dan Rp27.331.851/tahun/ha. Penelitian Utomo et.al (2014) menyatakan bahwa pendapatan usahatani karet di Desa Mait Hilir sebesar Rp3.000.000/bulan/ha atau sama dengan Rp36.000.000/tahun/ha.

Penelitian Syamsuddin (2019), menunjukan bahwa pendapatan usahatani karet di Kecamatan Indralaya Utara Kabupaten Oban Ilir Provinsi Sumatera Selatan diperoleh nilai sebesar Rp32.400.000/tahun/ha, lebih besar dibanding daerah penelitian. Hal ini karena harga karet mengalami kenaikan. Penelitian Hastuti dkk (2018), menyatakan bahwa pendapatan usahatani karet di Kecamatan Pelepat Ilir diperoleh nilai sebesar Rp37.567.461/tahun/ha, dan pendapatan ini lebih besar dibanding daerah penelitian, hal ini disebabkan karena adanya perbaikan harga karet. Firtiani dkk (2020), penelitian tentang kontribusi pendapatan petani karet, sawit dan palawija terhadap pendapatan keluarga petani, dengan hasil pendapatan petani karet di peroleh sebesar Rp52.630.500/tahun/ha. Tingginya pendaptan usahatani karet ini disebebkan oleh produktivitas karet dengan harga karet yang cukup tinggi.

Dari hasil penelitian apabila dilakukan analisis kontribusi pendapatan usahatani karet pada pendapatan rumah tangga diperoleh nilai sebesar 33,23 persen, sementara hasil penelitian Fitriani dkk (2020), diperoleh nilai kontribusi sebesar 47,57 persen. Kemudian apabila dibandingkan nilai kontribusinya penelitian Fitriani dkk (2020) lebih besar, hal ini dikarenakan pendapatan usahatani karetnya lebih tinggi. Miranda dkk (2015), dengan hasil penelitiannya menunjukan bahwa nilai kontibusi usahatani karet pada pendapatan rumah tangga sebesar 39,83 persen.

\section{Faktor-faktor yang Mempengaruhi Pendapatan Rumah Tangga Petani Karet}

Untuk mendapatkan modal estimasi yang baik, maka variabel tersebut harus bebas dari multikolinearitas, autokorelasi dan heteroskedastisitas. Melalui hasil estimasi model tidak diketemukan adanya gejala multikolinearitas, tidak terdapat permasalahan autokorelasi dan 
heteroskedastisitas. Dengan demikian model yang digunakan ini cukup baik. Hasil estimasi pendapatan rumah tangga petani karet tersaji pada Tabel 4 .

Koefisien determinasi $\left(\mathrm{R}^{2}\right)$ adalah suatu ukuran dalam analisis regresi, dimana dapat memberitahukan baik dan buruknya hasil analisis regresi yang akan diestimasi. Nilai koefisien determinasi sebesar 0,573 atau sebesar 57,3\%, mengindikasikan bahwa variasi pendapatan rumah tangga petani karet dijelaskan variabel umur, pendidikan, luas lahan, harga karet, pengalaman usahatani dan pekerjaan sampingan dengan sisanya sebesar $42,7 \%$ dijelaskan oleh variabel lain yang tidak dimasukkan ke dalam model.

Umur petani memiliki nilai t-hitung $(1,195)<$ t-tabel $(1,676)$ pada taraf kepercayaan 95\%. Artinya umur tidak berpengaruh terhadap pendapatan rumah tangga petani karet. Hal ini dimaknai bahwa umur muda dan umur tua sama-sama tidak mempengaruhi pendapatan rumah tangga petani karet. Hal ini kemungkinan yang dibutuhkan dalam peningkatan pendapatan rumah tangga petani adalah skill atau keterampilan untuk bekerja di sektor pertanian maupun di sektor non pertanian.

Tabel 4. Hasil estimasi pendapatan rumah tangga petani karet

\begin{tabular}{clrrr}
\hline \multirow{2}{*}{ No } & \multicolumn{1}{c}{ Variabel } & $\begin{array}{r}\text { Koefisien } \\
\text { Regresi }\end{array}$ & $\begin{array}{c}\text { Standar } \\
\text { Error }\end{array}$ & t-hitung \\
\hline 1 & Konstanta & 6,912 & 1,398 & 4,949 \\
2 & Umur petani (X1) & $-0,363$ & 0,304 & $-1,195$ \\
3 & Pendidikan (X2) & $-0,737$ & 0,705 & $-1,045$ \\
4 & Luas lahan karet (X3) & 0,894 & 0,171 & 0,520 \\
5 & Harga karet (X4) & 0,682 & 0,166 & $4,104^{*}$ \\
6 & Pengalaman usahatani karet (X5) & 0,724 & 0,153 & $4,705^{*}$ \\
7 & Pekerjaan sampingan (dummy) & 0,255 & 0,405 & $1,732^{*}$ \\
\hline & R2 & 0,573 & & \\
& F-hit & 10,751 & & \\
& F-tabel & 2,56 & & \\
& t-tabel & 1,676 & & \\
\hline
\end{tabular}

Sumber: Data primer diolah, 2019

Keterangan: *Signifikan pada taraf kepercayaan 95\%.

Tingkat pendidikan petani tidak berpengaruh pada pendapatan rumah tangga petani karet. Hal ini dapat dimaknai bahwa rendah tingginya pendidikan tidak akan mempengaruhi pendapatan rumah tangga petani karet. Petani karet pada umumnya memiliki tingkat pendidikan rendah (tamat SD), hal ini ketetahui mealui hasil wawancara. Mereka mendapatkan ilmu-ilmu di sektor pertanian hanya belajar dari orang tua. Kemudian bagi petani yang 
memiliki pendidikan lebih tinggi belum cakap untuk memahami dan mengembangkan ilmu dan teknologi di sektor pertanian dan non pertanian. dengan demikian tingkat pendidikan tidak berpengaruh pada pendapatan rumah tangga petani karet. Hasil studi sejalan dengan penelitian Wiriantoni, dkk (2014) dan penelitian Nugraha dan Alamsyah (2019).

Luas lahan karet tidak berpengaruh pada pendapatan rumah tangga petani. Hal ini dimaknai bahwa sempit dan luasnya lahan usahatani tidak menentukan tinggi rendahnya pendapatan rumah tangga petani karet. Kondisi ini karena pada umumnya tanaman karet rakyat masih menggunakan bibit yang kurang bagus atau menggunakan klon asalan, dan masih tingginya jumlah tanaman yang tua atau rusak. Dengan demikian tidak akan berpengaruh terhadap pendapatan rumah tangga petani karet.

Harga karet berpengaruh nyata pada pendapatan rumah tangga petani karet. Dimana dapat ditunjukkan dengan nilai t-hitung yang lebih besar dari ttabel dengan tanda koefisien regresi positif. Maka dari itu, apabila terjadi penambahan harga karet akan menambah pendapatan rumah tangga petani karet. Pada faktanya peningkatan harga karet akan sangat mempengaruhi peningkatan pendapatan petani, karena usahatani karet adalah pendapatan utama dalam meningkatkan pedapatan petani karet. Hal ini dapat dilihat melalui kontribusi pendapatan usahatani karet pada pendapatan rumah tangga petani karet sebesar $40 \%$. Kondisi ini sejalan dengan penelitian Hafsah, dkk (2014) dan penelitian Nugraha dan Alamsyah (2019). Oleh karena itu harga karet diharapkan tidak terlalu kecil sehingga pendapatan petani dapat meningkat dan dapat mencukupi kebutuhan keluarganya.

Pengalaman berusahatani karet berpengaruh nyata terhadap pendapatan rumah tangga petani, dengan tanda koefisien regresi yang positif yaitu sebesar 0,724 . Berdasarkan perhitungan dapat dimaknai bahwa semakin lama pengalaman berusahatani karet maka pendapatan akan meningkat. Pengalaman berusahatani karet yang semakin lama membuat petani dapat melakukan inovasi teknologi atau dapat memperbaiki cara berusaha tani karet, yang akan meningkatkan pendapatan usahatani karet dan meningkatkan pendapatan rumah tangga petani karet. Jika petani tidak mengubah cara fikir dengan menggunakan bibit unggul, penggunaan jarak tanam yang tepat, serta pemasaran yang terorganisir maka petani karet dapat meningkatkan pendapatan rumah tangga petani karet (Stiawan, 2014).

Dummy variabel pekerjaan sampingan berpengaruh terhadap pendapatan rumah tangga petani karet. Hal ini ditunjukkan oleh nilai t-hitung $>$ t-tabel, dengan nilai koefisien variabel dummy yang positif yaitu sebesar 0,255 . Hal ini dapat dimaknai bahwa dengan adanya pekerjaan sampingan dilakukan oleh petani karet akan dapat meningkatkan pendapatan rumah tangga petani kare. Ketika harga karet mengalami penurunan atau harganya rendah, maka hal ini akan mendorong petani karet untuk mencari pekerjaan 
sampingan (buruh bangunan). Sehingga akan menambah pendapatan rumah tangga petani karet.

\section{SIMPULAN DAN SARAN}

\section{Simpulan}

Berdasarkan hasil studi mengenai faktor-faktor yang mempengaruhi pendapatan rumah tangga petani karet di Desa Benteng Harapan, Kecamatan Maje Kabupaten Kaur, dapat diambil kesimpulan:

1. Penerimaan rumah tangga petani sebesar Rp6.026.650/bulan, pengeluaran sebesar Rp5.084.291/bulan, dan pendapatan sebesar Rp942.359/bulan

2. Harga karet, pengalaman berusahatani karet, dan pekerjaan sampingan merupakan variabel yang berpengaruh nyata terhadap pendapatan rumah tangga petani karet. Umur petani, pendidikan, dan luas lahan merupakan variabel yang tidak berpengaruh nyata.

\section{Saran}

Para petani karet diharapkan mampu menjaga kualitas karet lateksnya, dengan tidak mencampurkan benda lain untuk memberatkan timbangan. Di dalam pemasaran karet para petani hendaknya selalu diatur, para pedagang hendaknya tidak berusaha untuk menekan harga beli karet.

Bagi pemerintah diharapkan selalu menjadi motivator, inspirator bagi petani karet, sehingga petani karet merasa pekerjaannya didukung dan diperhatikan pemerintah. Disamping itu dapat menyediakan pekerjaan alternatif atau sampingan bagi petani karet.

\section{DAFTAR PUSTAKA}

Ali, J., Delis, A., dan Hodijah, S. 2015. Analisis Produksi dan Pendapatan Petani Karet Di Kabupaten Bungo. Jurnal Perspektif Pembiayaan dan Pembangunan Daerah. 2(4): 201-208

Devi,C. 2015. Analisis Pendapatan Perkebunan Karet Di Kecamatan Banyuasin III Kabupaten Banyuasin. Jurnal Bisnis dan Ekonomi. 6(2): 39-50

Endang. 2013. Kontribusi Pendapatan Usahatani Karet (Hevea brassiliensis) Terhadap Pendapatan Keluarga Di Kampung Sekolaq Oday Kecamatan Sekolaq Darat Kabupaten Kutai Barat. Jurnal Ekonomi Pertanian dan Pembangunan. 10(1): 28-34

Fitriani, I., Helmi, M., dan Itta, D. 2020. Kontibusi Pendapatan Petani Karet, Sawit dan Palawija Terhadap Pendapatan Keluarga Petani Di Desa 
Simpang Jaya Kecamatan Wanaraya Kabupaten Barito Kuala Kalimantan Selatan. Jurnal Sylva Scienteae. 3(4): 637-647

Hafsah, E, M dan Violetta, C, P. 2014. Analisis Pendapatan dan Tingkat Kesejahteraan Petani Karet Perkebunan Plasma di Desa Sungai Hijau Kecamatan Pangkalan Banteng Kota Waringin Barat Kalimantan Tengah. Bogor (ID). Institut Pertanian Bogor.

Hastuti, D., Delis, A., dan Rosmeli. 2018. Pengembangan Komoditas Kelapa Sawit dan Karet serta Dampaknya Terhadap Pendapatan Petani di Kecamatan Pelepat Ilir. Jurnal Sains Sosio Humaniora. 2(2): 92-104

Juliansyah, H dan Riyono, A. 2018. Pengaruh Produksi, Luas Lahan dan Tingkat Pendidikan Terhadap Pendapatan Petani Karet Di Desa Bukit Hagu Kecamatan Lhoksukon Kabupaten Aceh Utara. Jurnal Ekonomi Pertanian Unimal. 1(2) : 65-72

Mardiana, R. Abidin, Z. dan Soelaiman, A. 2014. Pendapatan dan Kesejahteraan Petani Karet Rakyat di Kecamatan Bumi Agung Kabupaten Way Kanan. Jurnal Ilmu Ilmu Agribisnis. 2(3): 239-249

Miranda, A., Lumangkun, A., dan Husni, H. 2015. Analisis Pendapatan Petani Karet Dari Hutan Tanaman Rakyat Di Trans SPI Desa Pangmilang Kecamatan Singkawang Selatan Kota Singkawang Kalimantan Barat. Jurnal Hutan Lestari. 3(4): 517-525

Natalia, S., Kesuma, S., dan Salmiah. 2013. Analisis Komparasi Tingkat Pendapatan Usaha Tani Karet Rakyat Dengan Usaha Tani Kelapa Sawit Rakyat Di Desa Buntu Bayu Kecamatan Hatonduhan Kabupaten Simalungun. Journal On Social Economic Of Agriculture And Agribusiness. 2(10): 1-15

Nugraha, I, S dan Alamsyah, A. 2019. Faktor-faktor yang Mempengaruhi Tingkat Pendapatan Petani Karet di Desa Sako Suban Kecamatan Batanghari Leko, Sumatera Selatan. Jurnal Ilmu-ilmu Pertanian Indonesia. 24(2): 93-100

Said, Y, M dan Junedi, H. 2008. Upaya Optimalisasi Lahan Peremajaan Karet dengan Tanaman Sela (Intercropping) di Keluarahan Sridadi Kabupaten Batanghari Provinsi Jambi. Jurnal Pengabdian pada Masyarakat. 45: 43-47

Stiawan, A., Wahyuningsih, S., dan Nurjayanti, E, D. 2014. Faktor-faktor yang Mempengaruhi Pendapatan Petani Karet (Studi Kasus di Desa Getas Kecamatan Singorojo, Kabupaten Kendal). Jurnal Ilmu-ilmu Pertanian. 10(2): 69-80

Soekartawi. 2016. Analisis Usahatani. Jakarta: UI Press

Sugiyono. 2002. Metode Penelitian Administrasi. Bandung: CV. Alpabeta Syamsuddin, T. 2019. Analisis Pendpatan Petani Karet Di Kecamtan Indra Jaya Utara Kabupaten Oban Ilir Provinsi Sumatera Selatan. Jurnal Ilmu Pertanian Agronitas. 1(2): 18-24 
Utomo, S., Asriati, N., dan Khosmas,F. 2014. Analisis Pendapatan Petani Karet Dalam Menunjang Kelanjutan Pendidikan Anak Di Desa Mait Hilir Kabupaten Sintang. Jurnal Pendidikan dan Pembelajaran Khatulistiwa. 3(8): $1-19$

Weriantoni., Srivani, M., Lukman., Febriani, F., Silvia., Maivira, E. 2017. Faktorfaktor yang Mempengaruhi Kesejahteraan Petani Karet (Studi Kasus di Nagari Limo Koto, Kecamatan Koto VII Kabupaten Sijunjung). Jurnal Teknologi Pertanian Andalas. 21(2): 164-175

Wulandari, S., Khaswatina, S., dan Eliza. Analisis Pendapatan Petani Karet Anggota Kub Di Desa Pulau Rambai Kecamatan Kampar Timur Kabupaten Kampar. Indonesian Journal of Agricultural Economics. 12 (1): 75-87

Wulansari, M., Aid, A., dan Wilda, K. 2012. Analisis Pendapatan Petani Karet Sub UPP Rantau Di Kecamatan Harungun Kabupaten Tapin. Jurnal Agribisnis Pedesaan. 2 (3): 206-213 